\title{
Preserving the marginal mandibular branch of the facial nerve during submandibular region surgery: a cadaveric safety study
}

\author{
Dimonge Joseph Anthony, Basnayaka Mudiyanselage Oshan Deshanjana Basnayake, \\ Yasith Mathangasinghe* (10) and Ajith Peiris Malalasekera
}

\begin{abstract}
Background: The marginal mandibular branch of the facial nerve is vulnerable to iatrogenic injuries during surgeries involving the submandibular region. This leads to significant post-operative morbidity. Studies assessing accurate anatomical landmarks of the marginal mandibular branch are sparse in South Asian countries. Present study was conducted to assess the relationship between the marginal mandibular branch and the inferior border of the body of mandible.

Methods: Twenty-two preserved cadavers of Sri Lankan nationality were selected. Cadavers were positioned dorsal decubitus with necks in extension. The maximum perpendicular distance between the inferior/caudal most ramus of the marginal mandibular branch and the inferior border of the body of the mandible was recorded on both hemi faces.

Results: Recorded maximum distance was $17.65 \mathrm{~mm}$ on left side and $10.80 \mathrm{~mm}$ on right side. Mean maximum distance, was $7.12 \pm 2.97 \mathrm{~mm}$. There was no statistically significant difference in the maximum deviation on left $(7.84 \pm 3.41 \mathrm{~mm})$ and right sides $(6.44 \pm 2.37 \mathrm{~mm})$.

Conclusion: Course of the marginal mandibular nerve is complex. If the distance of the incision in the posterior submandibular approach is less than $2 \mathrm{~cm}$ from the inferior border of the mandible, there is a high probability of damaging the inferior ramus of the marginal mandibular branch of the facial nerve.
\end{abstract}

Keywords: Marginal mandibular branch, Facial nerve, Mandible, Submandibular incision

\section{Background}

Facial nerve is the seventh cranial nerve, which supplies the muscles of the facial expression, sensory supply to the anterior two thirds of the tongue and secretomotor supply to the submandibular, sublingual and lachrymal glands. Marginal mandibular branch of facial nerve (MMBFN) is one of the main five terminal branches of the extracranial part of the facial nerve. It is given off within the substance of the parotid gland. There can be multiple rami of marginal mandibular nerve ranging from one to three [1].They run forwards and anteriorly towards the angle of the mandible deep to platysma and winds around the inferior border of the mandible. Then it turns upwards across the body of the

\footnotetext{
* Correspondence: yasith@anat.cmb.ac.lk

Department of Anatomy, Faculty of Medicine, University of Colombo, Kynsey Road, Colombo 08, Sri Lanka
}

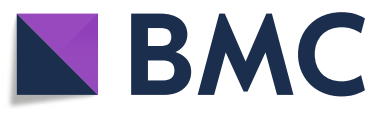

(c) The Author(s). 2018 Open Access This article is distributed under the terms of the Creative Commons Attribution 4.0 International License (http://creativecommons.org/licenses/by/4.0/), which permits unrestricted use, distribution, and

reproduction in any medium, provided you give appropriate credit to the original author(s) and the source, provide a link to the Creative Commons license, and indicate if changes were made. The Creative Commons Public Domain Dedication waiver (http://creativecommons.org/publicdomain/zero/1.0/) applies to the data made available in this article, unless otherwise stated.

mandible to pass under depressor angularis oris [2].It further divides to supply risorius and muscles of the lower lip and chin. Filaments given off at this point also communicate with the mental nerve [2].

Marginal mandibular nerve is at a vulnerable position during surgery of the area as it runs adjacent to the inferior border of the mandible. It is commonly damaged inadvertently at this site during surgeries involving submandibular region. Reported incidence of damage to the marginal mandibular nerve during submandibular gland removal is 0 to $20 \%$ [3-5]. But the true incidence is believed to be higher since most of these studies are retrospective and thus there is underreporting [6].

Iatrogenic trauma to the marginal mandibular nerve causes significant cosmetic disfigurement. Paralysis of the depressor anguli oris and the depressor labii inferioris cause 
inversion and flattening of the ipsilateral lip, thus disabling inferolateral movement [7].This results in an asymmetrical smile with elevation of the lower lip [7]. The deformity is more pronounced while the patient is crying [8]. This disfigurement leads to a significant perceived disability [6].

Hence, a sound knowledge regarding the surgical anatomy of marginal mandibular nerve at the upper neck in relation to the mandible is extremely important. Opinions in various textbooks diverge with regard to the relations of the marginal mandibular nerve [9]. Reported maximum downward deviation of this nerve from the inferior border of mandible is inconsistent (ranges from $+14 \mathrm{~mm}$ to + $40 \mathrm{~mm}$ in Caucasian populations $[1,10-15],-3.5 \mathrm{~mm}$ to + $30 \mathrm{~mm}$ in Mongoloid populations [16-20], +0.8 to + $13 \mathrm{~mm}$ in American populations [21-24] and $2.3 \mathrm{~mm}$ in African populations [25]). The results of these studies are summarized in the Table 1.

There is a scarcity of research evaluating the anatomical variations of the MMBFN from regional South Asian countries. Present study was conducted for the first time in a cohort of Sri Lankans to assess the relationship between MMBFN and the inferior border of the body of the mandible to make safe incisions when approaching submandibular region.

\section{Methods}

The dissections were conducted on self-donated cadavers. The study was ethically approved by the Ethics Review Committee, Faculty of Medicine, Colombo and was conducted in accordance with the guidelines set forth by Declaration of Helsinky.

Twenty cadavers of male and female adults of Sri Lankan nationality were selected randomly. Cadavers with deformed submandibular region were excluded from the study. All selected cadavers were preserved with conventional arterial injection method using $10 \%$ formalin as the main preservative. Cadavers were positioned dorsal decubitus, with the neck in extension approximately 15 degrees so as to simulate surgical positioning.

A skin incision was made $5 \mathrm{~cm}$ below and parallel to the lower border of mandible joining the anterior borders of sternocleidomastoid muscles on either side. A subplatysmal skin flap was made and reflected upwards to the lower lip. The marginal mandibular nerve was identified with careful blunt dissection under magnification and traced posteriorly to its origin within the substance of the parotid gland (Fig. 1). The nerve was left in place and dissected the superficial layers carefully to prevent mobilization of the nerve. Hence anatomical relations and distances to the adjacent structures were not disturbed. The perpendicular distance between the inferior border of the mandible and the inferior/caudal ramus of the marginal mandibular nerve was recorded on both sides. Measurements were recorded to the nearest $0.05 \mathrm{~mm}$ using a Vernier caliper [Manufacturer- Mitutoyo (Kanagawa- Japan) [Model No- 505-633-50]. If the inferior ramus was above the lower border of the mandible, the value was denoted with a minus, and vice versa. Data were analyzed using Statistical Package for

Table 1 A summary of the studies describing the maximum downward deviation of the MMBFN from the lower border of the mandible (MMBFN - Marginal mandibular branch of the facial nerve)

\begin{tabular}{|c|c|c|c|c|c|}
\hline $\begin{array}{l}\text { Year of } \\
\text { publication }\end{array}$ & Country & $\begin{array}{l}\text { Sample size } \\
\text { (hemifacies) }\end{array}$ & $\begin{array}{l}\text { Maximum } \\
\text { deviation of the } \\
\text { MMBFN (mm) }\end{array}$ & $\begin{array}{l}\text { Recommended distance for } \\
\text { the incision from the angle } \\
\text { of mandible }(\mathrm{cm})\end{array}$ & Special topographical findings \\
\hline $1996[10]$ & Germany & 55 & 14.00 & 2 & MMBFN had up to 4 branches \\
\hline $2012[11]$ & Turkey & 44 & 40.08 & None & $\begin{array}{l}\text { Branches of MMBFN - one branch (36.4\%), two branches } 63.6 \% \text {. } \\
\text { Communications with the buccal branch was present in } 4.6 \%\end{array}$ \\
\hline $2007[12]$ & Turkey & 50 & 10.04 & 2 & $\begin{array}{l}\text { MMBFN ran above the inferior border of the mandible in } 74 \% . \text { In } \\
22 \% \text { of the times the MMBFN divided into two branches at the } \\
\text { crossing point of the facial artery }\end{array}$ \\
\hline 2004 [13] & France & 54 & 17.5 & None & Single branch of MMBFN was found in $43 \%$ \\
\hline 1980 [15] & England & 110 & 12.0 & 2 & $\begin{array}{l}\text { Communications between the MMBFN and the buccal branch } \\
\text { were observed in } 8 \% \text {. Communications between the MMBFN } \\
\text { and the cervical branch were observed in } 12 \% \text {. }\end{array}$ \\
\hline $2016[16]$ & Korea & 29 & 17.0 & 2 & $\begin{array}{l}\text { There were no significant differences of the observed distances } \\
\text { in fresh and embalmed cadavers }\end{array}$ \\
\hline $2007[18]$ & China & 24 & 4.8 & None & \\
\hline 1991 [19] & China & 120 & $\begin{array}{l}\text { Between } 2.1 \\
\text { and } 3.0\end{array}$ & 3 & $\begin{array}{l}\text { Only } 10 \% \text { of the rami of the MMBFN ran below the lower border } \\
\text { of the mandible }\end{array}$ \\
\hline 2009 [20] & Korea & 85 & 19.8 & $\begin{array}{l}\text { Does not need to be far as } \\
3-4 \mathrm{~cm}\end{array}$ & \\
\hline
\end{tabular}




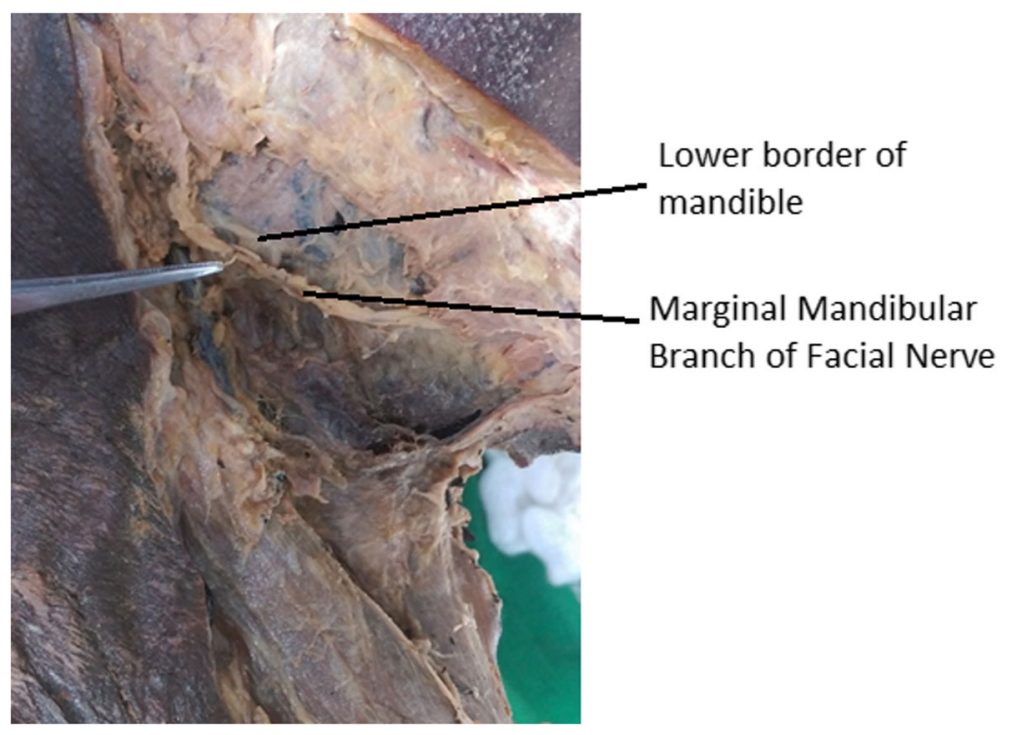

Fig. 1 Relation between the marginal mandibular branch of facial nerve (MMBFN) and the lower border of the mandible

Social Sciences (IBM SPSS) version 21 with a priori alpha of 05 .

\section{Results}

The MMBFN lied between the platysma and the investing layer of deep cervical fascia. The lowest ramus of MMBFN was located consistently below the lower border of the mandible in all the dissected hemifaces. Hence all the measured distances were positive. The distances were examined to determine the extent to which the assumption of normality was met. Skewness $=0.382(\mathrm{SE}=.365)$, kurtosis $=$ $0.068(.717)$ and the Shapiro-Wilk test $=0.974(\mathrm{df}=$ $42, p=.454)$ suggested that normality is a reasonable assumption.

Recorded maximum distance between the inferior border of the mandible and the caudal ramus of the marginal mandibular nerve on the left side was $17.65 \mathrm{~mm}$. The next greatest deviation was $13.40 \mathrm{~mm}$ on the same side. The maximum distance on the right side was $10.80 \mathrm{~mm}$. Mean maximum distance, was $7.12 \pm 2.97 \mathrm{~mm}$. An independent sample $t$-test showed that there was no significant difference in the maximum distance between the lowest ramus of the MMBFN and the lower border of the mandible on left (7.35 $\pm 2.63 \mathrm{~mm})$ and right sides $(6.44 \pm 2.37 \mathrm{~mm}) ; p>.05$. Ninety-five percent of the time, the outermost ramus of MMBFN lied within $6.09 \mathrm{~mm}$ to $7.65 \mathrm{~mm}$ distal to the inferior border of the mandible.

\section{Discussion}

The results of the study demonstrated that all the rami of the MMBFN were situated within $17.7 \mathrm{~mm}$ and $10.8 \mathrm{~mm}$ from the inferior angle of mandible on the left and right sides respectively. Even though the results suggested an asymmetrical distribution of the rami, it was not statistically significant. This asymmetry was noted in a study conducted by Saylam et al. [12].Similarly, there was no statistically significant difference in two sides in that study [12]. In contrast to the majority of scientific literature,the lowest rami of MMBFN were located consistently below the lower border of the mandible [10, 12, 17, 18, 20-22, 26]. However this was in corroboration with a French study [27].

If the distance of the incision in the posterior submandibular approach is less than $2 \mathrm{~cm}$ from the inferior border of the mandible, there is a high probability of damaging the inferior ramus of the MMBFN.

This safe distance has been the subject of debate for many years. The classical teaching has been to make the incision two finger breaths distal to the angle of mandible. This arbitrary cutoff has been refined by a number of studies. The safe distances that can be derived from the available scientific publications are $10 \mathrm{~mm}$ [1], $20 \mathrm{~mm}[16,23,28], 30 \mathrm{~mm}[10,19,21]$ and $40 \mathrm{~mm}$ [11]. A three centimeter distance was described in Risdon's technique $[29,30]$, which is a common approach in operative surgical procedures involving the submandibular region. But Baker and Conley found that the offshoots of MMBFN could be located 30 to $40 \mathrm{~mm}$ below the lower border of the mandible in lean subjects [14]. A summary of these studies are shown in Table 1. To date there is no guideline on this safe distance.

Special emphasis has been given to the positioning of the cadaver in similar research. We positioned the patient dorsal decubitus, with the neck in extension similar to position during surgery. This provides the surgeon with a good view. Hwang et al. found that the angle of 
neck extension does not change the position of the inferior ramus of the MMBFN with regard to the position of the surgical incision [17]. But surgeons should be aware that this relationship is liable to change if there is rotation of the neck [17].

Numerous studies have estimated the mean distance between the angle of mandible and the MMBFN. The objective of our study was to assess the maximum distance between the above mentioned structures for a safe incision. Therefore, describing the topographical variations of all the rami of MMBFN was out of scope of this study. Yang et al. described that there were no significant anatomical differences of MMBFN in fresh and embalmed cadavers [16]. Yet, we cannot rule out the possibility of such changes. Though we describe the maximum deviation of the nerve as a safe distance to make the incision, a more distally situated incision might be necessary to prevent occurrence of neuropraxia.

\section{Conclusion}

The course of the marginal mandibular nerve is subjected to a wide array of anatomical variations in the submandibular region. Surgical anatomy of this nerve might vary among different populations. Appreciation of these variations is important to reduce morbidity following surgeries involving submandibular region. Different from earlier reports, we found at least one ramus of each MMBFN located caudal to the inferior border of the body of the mandible. MMBFN is at highest risk of being damaged when a skin incision is placed 6.09 to $7.65 \mathrm{~mm}$ from the inferior angle of mandible.

Since South Asian countries have heterogeneous populations, detailed anatomic dissections in this context is needed to understand the subtle variations of MMBFN in a surgical point of view. A systematic review of available publications is necessary before guidelines are set. Neurophysiological studies are needed to confirm whether the results of the cadaveric studies could be directly applied on clinical grounds.

\section{Abbreviation}

MMBFN: Marginal Mandibular Branch of Facial Nerve

\section{Availability of data and materials}

Available from authors on request.

\section{Authors' contributions}

YM analyzed data. BMOD collected data. All the authors contributed meticulously to design the research, review literature, collect data and review the manuscript. All authors read and approved the final manuscript.

\section{Authors' information}

Prof. DJ Anthony MBBS, MS, FRCS (Edin.), Associate Professor in Anatomy,

Consultant General Surgeon.

Dr. Y Mathangasinghe MBBS, Lecturer in Anatomy.

Dr. BMOD Basnayake MBBS, Lecturer in Anatomy.

Dr. AP Malalasekera MBBS, MS, MRCS (Lond), Senior Lecturer in Anatomy,

Consultant Urological Surgeon, Editor in Chief (Sri Lanka Journal of Surgery).
Ethics approval and consent to participate

Ethics Review Committee, Faculty of Medicine, University of Colombo, Sri Lanka.

\section{Consent for publication}

Not applicable

\section{Competing interests}

The authors declare that they have no competing interests.

\section{Publisher's Note}

Springer Nature remains neutral with regard to jurisdictional claims in published maps and institutional affiliations.

Received: 7 June 2018 Accepted: 15 August 2018

Published online: 23 August 2018

\section{References}

1. Dingman RO, Grabb WC. Surgical anatomy of the mandibular ramus of the facial nerve based on the dissection of 100 facial halves. Plast Reconstr Surg. 1962;29(3):266-72

2. Standring S. Gray's anatomy - the anatomical basis of clinical practice. 41 ed: Elsevier; 2015.

3. Hald J, Andreassen UK. Submandibular gland excision: short-and long-term complications. ORL. 1994;56(2):87-91.

4. Ichimura K, Ki N, Tanaka T. Nerve paralysis after surgery in the submandibular triangle: review of University of Tokyo Hospital experience. Head Neck. 1997:19(1):48-53.

5. Leighton S. Submandibular gland surgery: an audit of clinical findings, pathology and postoperative morbidity. Ann R Coll Surg Engl. 1993;75(5):379.

6. Batstone MD, Scott B, Lowe D, Rogers SN. Marginal mandibular nerve injury during neck dissection and its impact on patient perception of appearance. Head Neck. 2009:31(5):673-8

7. Tulley P, Webb A, Chana J, Grobbelaar A, Harrison D, Tan S, et al. Paralysis of the marginal mandibular branch of the facial nerve: treatment options. Br J Plast Surg. 2000;53(5):378-85.

8. Moffat DA, Ramsden RT. The deformity produced by a palsy of the marginal mandibular branch of the facial nerve. J Laryngol Otol. 1977;91(05):401-6.

9. Schwember $\mathrm{G}$, Rodriguez A. Anatomic surgical dissection of the extraparotid portion of the facial nerve. Plast Reconstr Surg. 1988:81(2):183-8.

10. Rodel R, Lang J. Studies of the course of the marginal branch of the facial mandibular nerve. Laryngorhinootologie. 1996;75(6):368-71.

11. Karapinar U, Kilic C, Cetin B, Saglam O, Dursun E, Durmus M. The course of the marginal mandibular branch of the facial nerve in adult cadavers. An anatomic study. Saudi Med J. 2013;34(4):364-8.

12. Saylam C, Ucerler H, Orhan M, Uckan A, Ozek C. Localization of the marginal mandibular branch of the facial nerve. J Craniofac Surg. 2007;18(1):137-42.

13. Toure $S$, Vacher $C$, Bertrand JC. Anatomy of the marginal mandibular branch of the facial nerve. Rev Stomatol Chir Maxillofac. 2004;105(3):149-52.

14. Baker DC, Conley J. Avoiding facial nerve injuries in Rhytidectomy anatomical variations and pitfalls. Plast Reconstr Surg. 1979;64(6):781-95.

15. Ziarah HA, Atkinson ME. The surgical anatomy of the mandibular distribution of the facial nerve. Br J Oral Surg. 1981:19(3):159-70.

16. Yang HM, Kim HJ, Park HW, Sohn HJ, Ok HT, Moon JH, et al. Revisiting the topographic anatomy of the marginal mandibular branch of facial nerve relating to the surgical approach. Aesthet Surg J. 2016;36(9):977-82.

17. Hwang K, Huan F, Ki SH, Nam YS, Han SH. Location of the mandibular branch of the facial nerve according to the neck position. J Craniofac Surg. 2012;23(5):1488-90.

18. Liu AT, Jiang H, Zhao YZ, Yu DZ, Dang RS, Zhang YF, et al. Anatomy of buccal and marginal mandibular branches of facial nerve and its clinical significance. Zhonghua Zheng Xing Wai Ke Za Zhi. 2007;23(5):434-7.

19. Wang $T M$, Lin $C L$, Kuo KJ, Shih C. Surgical anatomy of the mandibular ramus of the facial nerve in Chinese adults. Acta Anat. 1991;142(2):126-31.

20. Kim DI, Nam SH, Nam YS, Lee KS, Chung RH, Han SH. The marginal mandibular branch of the facial nerve in Koreans. Clin Anat. 2009;22(2):207-14.

21. Woltmann M, Faveri R, Sgrott EA. Anatomosurgical study of the marginal mandibular branch of the facial nerve for submandibular surgical approach Braz Dent J. 2006;17(1):71-4. 
22. Baur DA, Kaiser AC, Leech BN, Landers MA, Altay MA, Quereshy F. The marginal mandibular nerve in relation to the inferior border of the mandible. J Oral Maxillofac Surg. 2014;72(11):2221-6.

23. Davies JC, Ravichandiran M, Agur AM, Fattah A. Evaluation of clinically relevant landmarks of the marginal mandibular branch of the facial nerve: a three-dimensional study with application to avoiding facial nerve palsy. Clin Anat. 2016;29(2):151-6.

24. Nason R, Binahmed A, Torchia M, Thliversis J. Clinical observations of the anatomy and function of the marginal mandibular nerve. Int J Oral Maxillofac Surg. 2007;36(8):712-5,

25. Potgieter W, Meiring JH, Boon JM, Pretorius E, Pretorius JP, Becker PJ. Mandibular landmarks as an aid in minimizing injury to the marginal mandibular branch: a metric and geometric anatomical study. Clin Anat. 2005;18(3):171-8.

26. Al-Hayani A. Anatomical localisation of the marginal mandibular branch of the facial nerve. Folia Morphol (Warsz). 2007;66(4):307-13.

27. Savary V, Robert R, Rogez JM, Armstrong O, Leborgne J. The mandibular marginal ramus of the facial nerve: an anatomic and clinical study. Surg Radiol Anat. 1997;19(2):69-72.

28. Nahai F, Nahai FR, Ford DT. Applied anatomy of the face and neck. In: Nahai F, ed. The Art of Aesthetic Surgery. St. Louis, MO: Quality Medical Publishing; 2005:874-5.

29. Cranin AN. Comparison of two submandibular incisions on the motor function of the lower lip. Oral Surg Oral Med Oral Pathol. 1975:40(3):327-32.

30. Ellis E, Zide MF. Surgical approaches to the facial skeleton. Philadelphia: Lippincott Williams \& Wilkins; 2006.

Ready to submit your research? Choose BMC and benefit from:

- fast, convenient online submission

- thorough peer review by experienced researchers in your field

- rapid publication on acceptance

- support for research data, including large and complex data types

- gold Open Access which fosters wider collaboration and increased citations

- maximum visibility for your research: over $100 \mathrm{M}$ website views per year

At $\mathrm{BMC}$, research is always in progress.

Learn more biomedcentral.com/submissions 